\title{
Notas de trabalho de Paulo Emilio Salles Gomes e Jean- Claude Bernardet. ${ }^{1}$
}

Os escritos de Paulo Emilio Salles Gomes e Jean-Claude Bernardet são observados a partir das suas primeiras anotações, feitas durante a projeção ou logo após, parte integrante dos trabalhos de análise dos críticos. Com a ajuda esclarecedora de Pedro Plaza Pinto e Margarida Adamatti podemos situar tais procedimentos iniciais no quadro concreto de suas atividades na época. O gosto pelo registro imediato, na vibração causada ainda na experiência da sala escura, se revela na presença de espírito no uso das palavras condizentes e sua capacidade descritiva, parecem querer algo dizer lidas hoje, em tempos de brilho ofuscante dos conceitos eclipsando as obras, num indício claro de declínio da assim chamada crítica imanente em nossos dias.

A partir das anotações sobre Zézero, Pedro Plaza Pinto enfatiza a aptidão de Paulo Emilio em lidar com narrativas não convencionais. Unindo a seleção de obras socialmente excluídas e a exigência de uma abordagem perita, seu ato crítico fundamenta-se numa ferramenta particular: a descrição das sequencias, realizada durante a projeção do filme. Neste caso, a escrita atém-se a uma percepção direta, guardando o esqueleto da trama e a síntese dos ritmos/rupturas da narrativa. No trato com Zézero, filme marcado pela crueza da sexualidade e da violência, a estratégia demonstra-se eficaz, chamando atenção para as relações entre escrita e percepção no método pauloemiliano.

As notas sobre Os Mansos, por sua vez, evidenciam um tipo de análise atenta aos enredos, estereótipos, piadas e influências cinematográficas da comédia erótica, que será usada por Bernardet como porta de entrada para uma análise da própria sociedade. Os manuscritos comentados por Margarida Adamatti, extraídos dos cadernos de anotações de filmes de Bernardet, fazem parte de um esforço contínuo de mapeamento dos lançamentos do cinema brasileiro pelo crítico. Em

\footnotetext{
${ }^{1}$ Nota dos editores de Fora de Quadro.
} 
alguns casos, as anotações diárias extrapolam a simples fixação do enredo dos filmes, levando a argumentações que serão usadas em artigos publicados na imprensa alternativa, como Movimento e Opinião. Entre a sala escura e a redação das notas em diário há, portanto, um pequeno lapso, atentando para o lugar da rememoração na escrita de Bernardet. Os comentários de Margarida Adamatti, de maneira particular, concentram-se numa etapa posterior, aquela da transposição dos manuscritos ao texto final publicado. Neste momento, fragmentos do material fixado nos diários tomam uma nova forma: a anotação para artigo.

Os dois conjuntos aqui apresentados, apesar de pontuais, sugerem a retomada de duas posturas, exigidas pelos próprios objetos e importantes para o estudo da crítica imanente. Por um lado, em Paulo Emilio Salles Gomes, uma vertente onde exercício escrito funde-se à percepção, à mimese entre escrita e obra, colaborando com a construção de novos métodos, usados para obras singulares. Por outro lado, a partir de Jean-Claude Bernardet, destaca-se a rememoração como ação de cunho coletivo, que reelabora o filme assistido, em sintonia com outros presentes na memória do crítico, priorizando a formulação de hipóteses e teorias mais abrangentes. Neste universo, em oposição ao gosto pessoal e à experiência afetiva, destacam-se as listas de filmes assistidos, os balanços anuais, bem como as anotações comparativas, presentes nos cadernos de anotações de Jean-Claude Bernardet. 